\title{
NUCLEAR PROLIFERATION AND ROGUE STATES: CONCERNS, REALITIES AND FUTURE THREATS
}

\author{
Dr. Rani Erum, Department of Political Science, Federal Urdu University Karachi, \\ Pakistan \\ http://www.rani.irum@fuuast.edu.pk \\ https://orcid.org/0000-0002-3845-8899
}

\begin{abstract}
:
Proliferation of Nuclear technology is accepted as a grave threat to the world. However, after the initial use of this lethal weapon at the end of World War II, the technology and techniques were transferred from secret government programs and by private organizations in various fields. Such transformation has been amplified by the privatization of civil nuclear energy projects, as well as other established industries in such way that at the time of need they can use the technology in making of nuclear weapons. Thus, this advancement of nuclear weapons program, material, technology and expertise are not only accessible for purchase from nongovernmental institutions but it has also increased the threat of its misuse by non-state actors. This study examines not only reasons of military nuclearization adopted by powers that be and their regional rivals but also provide comprehensive analysis of relating threats of acquiring this devastating technology by Rogue states and non-states actors and possible future perils faced by the world due to misuse.
\end{abstract}

Keywords : Nuclearization, WMDs, Regional Rivalries, Rouge States, Nuclear Terrorism, Non-State Actors.

\section{Introduction}

United States of America created the most destructive weapon devised ever by human beings and used it on the people of Japan and killing 340,000 people in no time. This invention gave an edge to US over other powers of the world. Soviet leader Joseph Stalin put in special efforts to get nuclear capability in record time and became the second nuclear power of the world in 1949; USSR's nuclear capability, on one hand created the balance of power between two superpowers of the world and on 


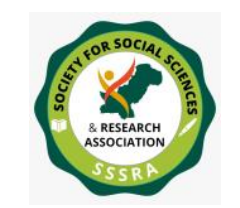

the other hand it introduced a new phenomenon named nuclear proliferation.

It is the process of acquiring the capability of producing nuclear weapons by one after another nation and able to launch a nuclear attack upon another nation (US Department of Defense, 2005). Therefore, it describes the spread of atomic weapons, fissile material, related technology and information. The proliferation of nuclear weapons began with the nuclear test of USSR in August 1949, followed by United Kingdom's nuclear test in October 1952 and then by France in 1960 and Peoples Republic of China in 1964. India detonated an atomic device in 1974 and Pakistan tested its nuclear weapon in 1998 followed by North Korea in 2006.

\section{CONCERNS ON NUCLEAR PROLIFERATION}

The rapid proliferation of nuclear capability among the European countries led to an alarming situation for American policy makers because soon it signified a symbol of prestige and pride for nuclear powers. The Cold-War was recognized as a 'first atomic age' because of possession of nuclear weapons in a vertical direction (only five countries achieved to acquire it). All these countries considered themselves in first order among states. The Antarctic Treaty of 1959 was the first post war arms limitation agreement introduced by White House, showing its initial concerns. It used as an example for later arms control agreements such as the prohibition of nuclear arsenal testing in space, seabed and the many nuclear free zones. In October 1962 Washington discovered a secret attempt by the Soviet Union to lodge nuclear missiles in Cuba. The crisis was resolved by the public and private assurances by Oval office, that it would not sponsor an invasion of Cuba and removes its intermediate range ballistic missiles from Italy and Turkey. Before the Cuban missile crisis, a nuclear war appeared to be a speculative possibility and a nightmare for nuclear strategists. The second arms control agreement was negotiated between three existing nuclear powers: USA, USSR and the United Kingdom. The Limited Test Ban Treaty (LTBT) was signed in August, 1963 and came into force in October 1963. It prohibited its signatories 


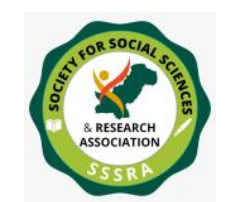

from conducting nuclear experiments in the atmosphere, it was a substantial "clean air act" (Young, 1972: 86). These early efforts of the pioneers of nuclear weapons reflect there apprehensions for their devastating invention. In 1963, President John F. Kennedy predicted that there would be from 15 to 25 states with nuclear weapons by the 1970 s (Seaborg, 1981: 198-99). Americans followed a dual strategy of nonproliferation because of strengthening its status and the greatest security concern of the military capabilities of USSR throughout the Cold War. It also considered China and regional states such as North Korea as potential threats but it was too busy countering the Soviet threat and did not focus on other threats of late.

Washington and Moscow both developed multiple types of nuclear weapons and their delivery system because of mutual distrust and hostility. By 1970 nuclear weapons possessed by each side numbered in the thousands, over 26,000 warheads in the US alone and over 11,000 in the USSR (Margulies, 2010: 06). On one hand both powers increased their nuclear arsenals and on other hand they were trying to stop horizontal proliferation by introducing the Nuclear Non-Proliferation Treaty (NPT) signed in 1968 and was protracted in 1995. Nearly all countries joined the NPT except India, Pakistan, and Israel. In 1969 the US and USSR opened negotiations to control long-range ballistic missiles in the Strategic Arms Limitation Talks (SALT). The SALT I agreement, the Anti-Ballistic Missile (ABM) Treaty and an provisional agreement on belligerent arms were signed in 1972, to be followed by a new round of negotiations called SALT II that resulted in an agreement in 1979 which was signed but not ratified by the United States (Caldwell \& Williams Jr, $2^{\text {nd }}$ ed, 2012:57-58). United States also showed its double standards about Israel's nuclear arsenals which developed in late 1960s, and was never criticized for spread of nuclearization. This dual standard has increased the proliferation of WMDs in the Middle East and South Asia. India used this double policy as a reason for its weapons program and the series of its nuclear tests motivated Pakistan and it replied in a same way and acquired nuclear capability in 1998. Although America made some serious efforts to stop vertical and horizontal nuclear proliferation by Treaties, talks and threat of sanctions on states like India, Pakistan and North Korea but nothing was 


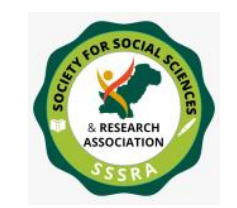

exclusive enough to stop the " 2 nd nuclear age". Optimistic expectations of disarmament and Non-nuclear proliferation in a post-Cold-War era driven by the 1991, (Strategic Arms Reduction Treaty) START I and by START II in 1993. By these treaties for the first time, America and Russia agreed to reduce the number of their nuclear warheads and eradicate some categories of weapons (Heywood, 2011: 267). The two treaties called for the most significant reductions in long range nuclear warheads and bombs under any arms control agreement ever concluded. But such early optimism very quickly fainted because of the continued nuclear strategies of established nuclear states and easy availability of ready nuclear technology for everyone. Just before the new millennium attempts to nuclear arms reduction started again and START III meetings began in Moscow in 1999 but it ended on a disagreement on ABM (Anti-Ballistic Missile) treaty. Thus, the $21^{\text {st }}$ century began with the fears of misuse of nuclear arms by rogue states and non-state actors.

\section{FEAR OF NUCLEAR TERRORISM AND THE COUNTERING EFFORTS}

The new millennium began with the fear of nuclear terrorism and attacks of 9/11 shattered the whole world. The possibilities of use of nuclear weapons in any terrorist activity permitted the US administration to take steps towards arms control and disarmament. In 2002 America and Russia signed Strategic Offensive Reduction Treaty (SORT) but it again proved just a nobleman's treaty because it contained no certification methods, permitted both countries to deploy in between 1700 to 2,200 warheads and put the rest of the warheads in stowage rather than eliminating them. The treaty also allowed both states to withdraw from the treaty on a three months' notice. This strategy of recognized nuclear powers increased the significance of atomic weapons for other states and weakened the moral position of nuclear powers of the world. In 2006 North Korea tested its nuclear weapons and became the $9^{\text {th }}$ nuclear power. It was the biggest failure of White House nuclear strategy, though it already tagged the phenomenon of rogue states with them but it could not hold them from acquiring nuclear technology. President Obama came into office in 2009 with the determination to revive efforts to reduce the world's 


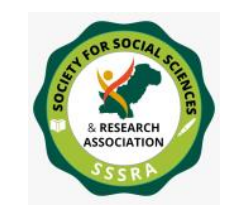

stockpiles of nuclear arsenal. On $5^{\text {th }}$ December 2009, Obama administration discussed an agreement with Russia called New START. It was signed in April 2010 and was designed to supersede the 2002 Strategic Offensive Reduction Treaty. The New START Treaty needs that Moscow and Washington decrease their tactical fissile arsenals to 1,550 warheads each within seven years of the agreement's entry into force. Both sides will also be limited to a combined total of no more than 700 deployed ICBMs (Intercontinental Ballistic Missile), SLBM (Submarine-Launched Ballistic Missile) and nuclear capable heavy bomber (Caldwell \& Williams Jr, $2^{\text {nd }}$ Ed, 2012: 59). The treaty also contains clauses for on-site inspections, data exchanges and the use of so called national means of verification. The American Senate ratified the treaty on December 22, 2010. In 2009, the Department of Defense also discloses plans to deploy a nuclear bunker buster known as Massive Ordinance Penetrator (MOP) on B-2 bombers. Many experts were convinced that the plan was designed to give a signal Iran that its nuclear program could not be safe even if it is situated underground. The efforts of arms control in the $21^{\text {st }}$ century remains important but not as vital as during the Cold-War.

\section{ROGUE STATES AND NUCLEAR PROLIFERATION}

The rogue state phenomenon rose at the end of the twentieth century. Basically, those nations who refused to act by prohibited rules of state-supported terrorism, proliferation of WMDs, and brutal treatment of their own citizens (Tanter, 1999: 04). The American Congress prepared the list of terrorist states in the Export Administration Act under the Department of State in 1979. The states on the list were also identified as rogue states. Few years later Department of State removed South Yemen because of its unification with North Yemen. Libya was delisted because of its voluntary abandonment of WMDs and acceptance of international inspection. Iraq's was removed from the list because of American invasion and occupation in 2003. The Bush administration also delisted North Korea after their negotiations with Pyongyang. Among the rest of the four states, Iran gathered more attention because of its nuclear intentions. 


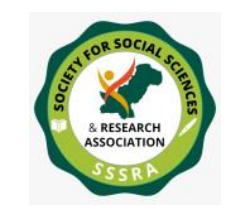

\section{IRAN}

Iran is a country of 75 million people situated in the Persian Gulf region. It is a Shia Islamic regime, established by popular referendum under its constitution. It is an important focal point for American foreign policy in $21^{\text {st }}$ century. US Government strongly believes that Iran's nuclear projects are progressing toward nuclear arms. It is the major concern for the White House, because of two reasons. Firstly that Iran can use it against Israel and US forces in the region; secondly, it fears that Tehran may provide nuclear munitions to terrorists which can be used against USA or its allies. Although Iran signed the NPT and it also has a history of friendly relation with America but since its revolution of 1979, it has become an axis of evil for the West.

America's intelligence agencies and their government officials have assessed many threats from the Iranian Islamic regime. Director of National Intelligence John Negroponte provided his assessment in his 2006 Annual Threat Report that Iran is seeking nuclear weapons. The report also claims that Iran has an invasive chemical and biological arms research and development program as well as it has the maximum number of ballistic missiles in the region. They also raised the concern that Iran may assemble nuclear weapons into its ballistic missiles. US believes that Tehran is involved in facilitating terrorist groups in Lebanon, Palestine and elsewhere. The report also points that the Iranian national security officials are actively associated with the insurgency in Iraq.

The contours of the Iranian threat has expanded over the last few years because of the public statements of Iranian officials against Washington and Tal Aviv and ongoing Iranian nuclear research. White House claimed that Iran has provided financial support and weapons to Hezbollah against Israel from 2006 to 2012. Therefore, according to the US Administration, Iran bears significant responsibility for violence in the Middle East especially in Israel, Syria and Lebanon. 


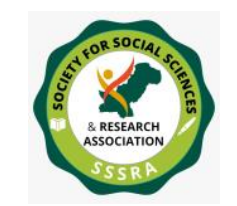

\section{NUCLEAR PROGRAM OF IRAN}

The international community has showed concern on Iranian's nuclear program for many years although Iran signed the NPT in 1968 and has insisted constantly that its nuclear activities are for peaceful purposes. Its peaceful fissile program started in 1950s with the help of USA as a part of Atom for Peace program of Washington and continued till the 1979 Iranian Revolution. Any major defilement of the NPT by Iran were not revealed before 2002. In August 2002, the Mujahideen-e-Khalq (MEK) discovered that Tehran had two furtive nuclear sites;

- The gas centrifuges plant at Natanz

- The uranium-conversion plant at Asfahan.

The Natanz plant holds the capacity for enriching uranium for electricity production or at a high level, for nuclear armaments. Whereas, the Asfahan plant is to refine uranium to various levels of potencies. One more plant at Ark was discovered the same year, which developed plutonium from a heavy-water production facility. IAEA discovered an initial program of 100 functioning centrifuges used for uranium enrichment at Natanz facility. It also found components of 50,000 centrifuges that can produce highly enriched uranium (HEU) for 25 to 50 bombs per year (Henriksen, 2012: 90). The IAEA inspectors also exposed the Yellow cake (refined uranium) imported from China and Pakistan. Other sources also discovered that Asfahan plant prepared for converting the yellow cake in to high enriched uranium for nuclear weapon. This discloser led IAEA to conclude that Iran has committed violations of NPT; it also called Iran to stop its uranium enrichment plants and demanded it to sign Additional Protocol to the NPT. It also set a deadline of $31^{\text {st }}$ October, 2003 for compliance and its pledge in UN Security Council, which Iran did. The apprehensions against Iran spread out all over the Western World therefore, substantive talks were held between Germany, France and Britain, commonly known as E-3 with Iran. These talks concluded on an agreement of temporary suspension of Iran's uranium enrichment in November 2004. When Mahmoud Ahmadinejad, former mayor of Tehran entered in the 


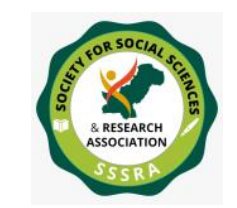

presidency in 2005, he immediately rejected his ancestor's agreement and proclaimed the continuation of their enrichment program. Since then, Iran disclosed very little information about its nuclear enterprises. It still aims to keep the world in the dark about its nuclear industry and through this it is trying to secure its nuclear weapons from US or Israel's preemptive strikes. Reports are also in circulation that Iran had established some of its nuclear plants underground with concrete layers as added protection against conventional penetrating warheads (Henriksen, 2012: 91). Americans believes that all these efforts have only further disturbed the international political scenario and due to the different global security environment, it is the responsibility of the only super power to halt Iran from further nuclearization.

\section{IRAQ}

Iraq is the ideal example of a rogue state which is now delisted from the official State Department list after the invasion of USA in 2003. Before the invasion, Iraq came up to the established criteria of rogue phenomenon. Under Saddam Hussein, attack on two neighboring countries had destabilized the Persian Gulf region. United States proclaimed that it also supported terrorism abroad and pursued obtaining WMDs. Internally Saddam regime, crushed oppositions, killed possible rivals and brutally annihilated thousands of Kurdish and Shiite population of the country as well as used chemical weapons against some of them.

American's realized the importance of Iraq in the region towards the end of the Cold-War. It tried to use Saddam Hussein as a counterweight to Iran after the Iranian revolution. Washington helped Iraq militarily during the eight year, Iran-Iraq War (1980-1988) and provided satellite intelligence to Iraq against Iranian ground forces. Critics of the regime argued that sharing of intelligence of CIA motivated Saddam to use chemical weapons against Iran, an open violation of the 1925 Geneva accords prohibiting gas warfare. The chemical assaults become one of the reasons of UN-negotiated cease fire between Baghdad and Tehran in August 1988(Tehranian \& Clement, 2005: 120). At the same time Saddam's regime used this prohibited weapon on its own rivals and killed 


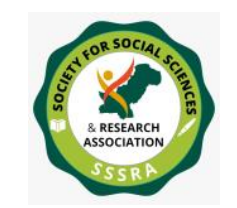

thousands of Kurds by chemical weapons. Beside this Iraq reclaimed its rightful possession of Kuwait as its $19^{\text {th }}$ province which had been stolen by Europe's colonial mapmakers. It also accused Kuwait of exceeding its OPEC (Organization of the Petroleum Exporting Countries) quotas for oil production. On $2^{\text {nd }}$ August 1990, Iraq invaded Kuwait for the fulfillment of its claim. Within hours of the invasion, Kuwait and US delegations requested a meeting of the United Nations Security Council, which passed Resolution 660, condemning the invasion and demanding withdrawal of Iraqi troops (Finlan, 2003: 29). On 6 August, Resolution 661 was passed which placed economic sanctions on Iraq, later naval blockade was also enforced but none of these affected Saddam's regime. Finally under the UN resolutions, United States gathered a coalition of forces from 34 countries against Iraq's aggression. On January $17^{\text {th }} 1991$ the Operation Desert Storm was commenced against Iraq which ended on $28^{\text {th }}$ February 1991 ending its annexation of Kuwait (Pollack, 2002: 76). This war is also known as Gulf War I. Both Washington and UN bestowed a number of public excuses for taking part in the conflict, such as the Iraq's violation of Kuwaiti territorial integrity, safety of Saudi Arabia, whose position in the region as an ally of Washington was incompatible, and as a main supplier of oil, gave it a significant geopolitical status. President Bush launched a strong Repression policy after the end of Gulf War I.

The Bush strategy failed to mould Baghdad accordingly. Saddam Hussein suspended the United Nations Special Commission (UNSCOM) inspection because UN inspectors discovered that an Iraqi official had secretly hidden 650,000 pages of material concerning biological weapons on a chicken farm outside Baghdad. After examining these materials, the inspectors realized that Iraq had developed both defensive and an offensive biological weapons program. Saddam blocked the UNSCOM assessments as a mode to increase the UN prohibitions. White House installed three days air strikes with French, British and its own warplanes to punish Iraq. At once Saddam backed down and allowed the IAEA inspectors to restart their search. These tense relations continued after the Bush era and Baghdad threw up road blocks in the way of UNSCOM. USA and UK started Operation Desert Fox in December 1998 which was the most intense military operation of Washington before the 


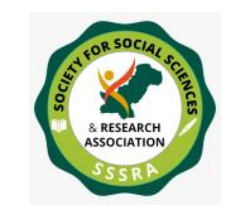

Iraq War. It was applied on Iraq only because it tagged with rogue phenomenon by America's military diplomacy.

The end of rogue nature of Iraq came in 2003 when US invaded Iraq again. This full scale attack was completely different from American policy towards other rogue states. The climax of the war was the beginning of the insurgency in Iraq, the deaths and carnage extended across the country, which proved devastating. It not just damaged Bush's antiproliferation campaign in Gulf region but through this war American's own rogue image emerged. The only yield of this war is that Iraq is not remain in a rogue list bent on manufacturing nuclear arsenals and it may set an example for other rogue nations from US attacks.

\section{NORTH KOREA}

Democratic People's Republic of Korea (DPRK) is the third major country on the list of rogue states. It is among the most underprivileged nations in the third world except armaments and uncanny deal - making skills. It exercised brinksmanship, publicized saber-rattling threats, much more than any other rogue state and achieved a chain of political feats against the US. In fact, its belligerency escalated over the years. The conflict among the two states began after WW II. At that time, Korea was already divided into North and South but this division was not permanent. This partition became perennial after the Korean War (1950 1953). Since 1953 both parts of Korea took steps into different directions, Pyongyang became the communist state and South Korea joined the capitalist block. The tension between DPRK and Washington initially had ideological reasons but afterwards other areas of conflicts arose, such as nuclear proliferation, trade links and diplomatic connections. The most severe conflict between the two countries was the nuclear desire of North Korea which was facilitated by USSR. This dispute has now ended because of the joining of DPRK in the exclusive nuclear club in 2006 and recent agreements between two states.

\section{NUCLEAR PROGRAM OF NORTH KOREA}




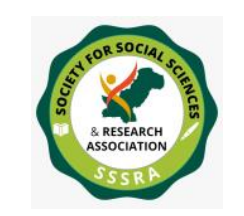

The ambition of acquiring nuclear weapons by Pyongyang begins at the time of rise of communism with the help of USSR and China. North Korea was economically and militarily robust than South Korea. However, its atomic program has originated and expanded greatly after 1950-53 Korean War. North Korea and USSR signed a nuclear cooperation agreement in 1959, according to which Moscow will provide the basic fissile training and technology over the next 30 years to North Korea. The ultimate evidences were found during the Reagan period when US spy satellites captured the pictures of possible nuclear "breakout" in early $80 \mathrm{~s}$. President Ronald Reagan immediately pressurized the Soviet Union to persuade its ally to enter into the NPT. The reaction of Washington against DPRK and other listed states during 1990s was based on two major war threats on which its war planning originated. According to Americans Baghdad and Pyongyang blew war trumpets and both have same intentions but it was not possible for US to confront on two grounds at the same time so it dealt North Korea diplomatically.

Later under the Clinton era intelligence found that Kim regime was boarding on uranium processing for nuclear armaments. This news was the test for new White House resident, President George W. Bush. Washington not only dealt with North Korea very aggressively but it also charged Pakistani scientist, Doctor Abdul Qadeer Khan of selling the nuclear capability to North Korea, Iran and Libya. United States declared in October 2002 that uranium enrichment is a multinational problem. Washington decided to engage all those countries who had close borders with Pyongyang. In late September 2005, the US Treasury's Operation Smoking Dragon Imposed financial sanctions on Banco Delta Asia (BDA) in Macau. Pyongyang retaliated against American sanctions very aggressively and fired not only a long range missile but also conducted a nuclear test. Kim regime tested an underground nuclear device in the country's north east corner on October 9, 2006. Prior to detonation, it informed Beijing that it would conduct a test in the range of 4 kilotons (a 4,000-ton TNT) equivalent. Sensors recorded a yield of less than 1 kiloton, or below a 1,000-ton TNT magnitude (Henriksen, 2012: 126). It was much smaller than that bomb which was dropped on Nagasaki by Washington in 1945. The United States clenched a moment in condemning the nuclear 


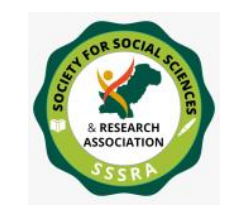

experiment. US President considered it a "proactive action." Apart from verbal statements Washington did not undertake any military action against Pyongyang.

North Korea tested its nuclear weapon against all warnings but after the test criticism against Pyongyang was not as intense as the apprehension that it was advancing at high speed towards an atomic capability. United Nations Security Council passed Resolution 1718 against Kim Regime. It banned the transfer of fissile material and any other thing which can be useful in creation of WMDs. It also prohibited portable assets of persons associated to the country's weapons plans. Moreover, it authorized all countries to check cargo arriving or departure North Korea to identify prohibited arms (Henriksen, 2012: 127). The sanctions further protracted to amenity redeems. Furthermore Washington started negotiations with China, Japan, Russia and South Korea to impose more sanctions on DPRK, especially with China because it had more influence on Pyongyang than any other state but in the end Beijing accepted a soft restrictions program than the prior US draft. The PRC shares 870 miles borders with North Korea and has critical economic link with it. In February 2007, the Bush administration finally reached an agreement with North Korea, known as $13^{\text {th }}$ February Agreement. This agreement offered $\$ 400$ million heavy fuel oil plus benevolent and financial aid to the DPRK, in exchange for dismantling its nuclear plants within 60 days and a re-entry of international inspection team. At the same time, the Oval office vowed to take out North Korea from its list (Kessler, Washington Post, 14 February, 2007).

North Korean did not regard any agreement, passed the deadline of 60 days and also helped Syria for its nuclear program but Bush the administration did not take any military action against it. Due to this leniency, Pyongyang further extended its nuclear program and on May 2009, announced its second nuclear detonation to a pejorative world. The subversive blast went off at Kilju in the northeast of the country. It produced a 4.5 magnitude earthquake. The explosive registered in the 2- to 4- kiloton range, two to five times greater than 2006 explosion. President Barak Obama stated at the Rose Garden that "North Korea is directly and 


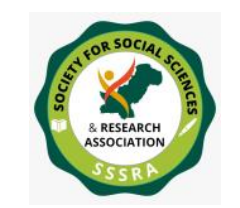

recklessly challenging the international community," he vowed to "take action against what he characterized as "a blatant violation of international law" (Hun New York Times, 10 April, 2009). Kim regime considered Washington's bark worse than its bite because America had deliberately adopted the policy of ignoring North Korean action which boosted Pyongyang's spirits and actions. Kim regime claimed successful underground tests of Hydrogen bomb on September 3, 2017. Although the new US president Donald Trump gave an aggressive reaction and UN Security Council again passed the resolution against DPRK but it did not hold them because of lenient behavior of world powers. This attitude expresses the acceptance of nuclear-armed North Korea by Washington and Beijing. Now the question arises if United States accepted North Korean nuclearization then what is it going to do with Iran's nonmilitary reactors and why it has supported Israeli strikes against Syrian nuclear sites? Does the white house has different approaches for different regions?

\section{LIBYA AND SYRIA}

Libya and Syria emerged as lesser rogue states after the ColdWar. White House included both the countries in the list of rogue states. Their autocratic rule, ignited assertions, human rights violations, terrorist support, or initiative to protected WMD comprised the earmark of rogue manners.

Libya initiated its WMD program under Colonel Muammar alQaddafi. Qaddafi's government was a self-style revolutionary power involved in terrorism against the Western world before it developed WMDs. After many years' of prohibitions and seclusion due to its terrorist motives, Libya retreated from terrorist activities and give up its WMD program and become an exemplar of rogue abdication, transition and limited global reacceptance. It opened its territory for IAEA inspections and rejoined the global community. Washington delisted Libya from rogue state list because of its strategic change.

Syria too was supposed to be a rogue player by Washington. Apart of its use of extremism as a state tool and its quest for WMDs, it did 


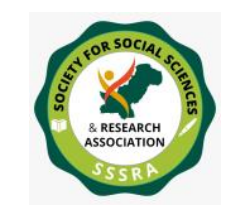

not show the same attitude as of Iran, Iraq or North Korea since disintegration of USSR. Damascus's chemical and nuclear programs started before 1973 (Rubin, 2007: 221). Its Chemical units were built near AlSafira, Hama and Homs. North Koreans provided assistance to Syrian experts to made their own mustard, sarin and nerve gases secretly. Despite the chemical weapons Syrian urge of nuclear weapons also disturbed Washington for many years. Although it did accept and approve the NPT in 1969 but its alarming profile raised tension in the Western camp. Damascus efforts to acquire nuclear capabilities started during the decade of $80 \mathrm{~s}$ and it attained first nuclear reactor from China which started working in 1996 but it was too small to become a threat of nuclear proliferation. Syria's alleged nuclear munitions program was uncovered by the abrupt attack of September 6, 2007, in which Israeli warplanes bombed on a country's northeastern site near the town of al-Kibar (Albright, 2010: 168). This military attack disclosed the Pyongyang-Damascus collaboration because it was reported that many North Koreans lost their lives at the blast venue. Though, Israeli assault destroyed the covert reactor of Syria but intelligence reports still suggest its secret activities. Therefore, Washington took strong actions against Bashar al- Assad's government and imposed financial sanctions. These sanctions are for nuclear violations and for its repression against anti-regime demonstrators which almost finished Syrian nuclear intentions and now it is not a big threat to global peace. Thus, Syria and Libya are the lesser rogue states in the American list because of their limited role in world politics.

\section{CONCLUSION}

United States and Western powers always exhibit their desire for a nuclear free world and it seems that they took every step to stop nuclear proliferation but if their policy makers really want a complete elimination of nuclearization then they will have to wrap up their two fold policy because only then the task of a nuclear free world can be achieved. North Korean test of Hydrogen bomb is the prime example of their double policy. On the other hand possibilities of transfer of nuclear technology to non-state actors are still not fully exterminated. The disintegration of USSR turned many new countries of Eurasia as host of soviet nuclear technology. 
Many of them need financial assistance for strengthening their position and non-state actors can offer them huge amounts of money in exchange of this arsenal. This picture articulates that without removing fiscal disparities and dual policies the fear of use and transfer of nuclear bombs cannot be wiped out. Despite acquiring similar policies for all nations, there is a need of solving the disputes between arch rivals and combating nations for independence and rights such as disputes of Kashmir, Crimea, Palestine, Korean peninsula and Chechnya. It is also important to monitor those nations who procure nuclear technology for peaceful purposes but when they desire they can change it into military purpose such as India who obtained nuclear capability purely for non-military use but when China tested its Atomic bomb, Delhi converted its capability into armed munitions. It is also the responsibility of NSA (Nuclear Suppliers Group), who is the representative of non-military use of nuclear technology that any country which attains nuclear capability must stick to its commitment and should not convert their capability for military means. The dream of a nuclear free world is attainable yet hard to accomplish. 


\section{Reference:}

Albright, D. (2010). Peddling Peril: How the Secret Nuclear Trade Arms America's Enemies. New York: Simon and Schuster.

Caldwell, D., \& Williams Jr, R. E. (2016). Seeking security in an insecure world. Rowman \& Littlefield.

Joint Chiefs of Staff Washington DC. (2005). Department of Defense Dictionary of Military and Associated Terms. Ft. Belvoir : Defence Technical Information Centre. http://www.thefreedictionary.com/proliferation+\%28nuclear+weapons\%29 (Retrieved: 12 Aug, 2017).

Finlan, A.(2003). The Gulf War 1991. New York: Routledge.

Henriksen, T. (2012).America and the rogue states. New York: Palgrave Macmillan.

Heywood, A. (2011). Global Politics. New York: Palgrave \& Macmillan.

Hun, C. S. (10 April, 2009). North Korean Nuclear Claim Draws Global Criticism. New York Times, p. AI

Kessler, G.(14 February, 2007). US Flexibility Credited in Nuclear Deal with N. Korea. Washington Post, p. All. Viva Books.

Margulies, P. (2010). Nuclear Non-Proliferation. New York:

Pollack, K.M. (2002). The Threatening Strom: The Case for Invading Iraq. New York: Random House.

Macmillan.

Rubin, B.(2007). The Truth about Syria. New York: Palgrave 
Seaborg, G. (1981). Kennedy, Khrushchev and the Test Ban. Berkeley: University of California Press.

Tanter, R. (1999). Rogue Regimes: Terrorism and Proliferation. New York: St. Martin's Press.

Tehranian, M. \& Clement, K. P. (2005). America and the World: The Double Bind. New Brunswick: Transaction Publishers.

Warrick, J. \& Kessler, G. (March 10, 2003). Iran's Nuclear Program Speeds Ahead. Washington Post, Al.

Young, Elizabeth (1972). A Farewell to Arms Control. Baltimore: Penguin. 